\title{
THE RESEARCH OF THE FORMATION OF MOTOR SENSATIONS AND PERCEPTIONS IN CHILDREN OF THE THIRD YEAR OF LIFE IN A PRE-SCHOOL SETTING UP
}

\section{Svitlana Vasilieva ${ }^{1}$}

DOI: https://doi.org/10.30525/978-9934-588-15-0-3

Abstract. In order to reveal the problem of motor development of children in the third year of life, the article focuses on the study of the formation of motor sensations and perceptions in children, namely the statement that allowed us to attain the common goal, the object of study, where the object of our study is mental (cognitive, emotional, volitional) processes that affect the motor development of the child. The methodological basis of the study is the theory of personally oriented upbringing of the child I. Beha; classical approaches to the formation of arbitrary personality behavior (L. Vygotsky, G. Kostyuk, O. Leontiev); state regulations on preschool education in Ukraine; scientific conceptual approaches to the organization of public preschool education in Ukraine (L. Artemova, A. Bogush, N. Gavrish, O. Kononko, K. Kruty, S. Kuzmenko, T. Ponymanskaya); used bibliographic method for systematization and classification of philosophical, psycho-pedagogical, medical literature, definition of theoretical bases, content and structure of leading categories of research on motor development in young children; method of theoretical analysis to determine the criteria, indicators and levels of motor (kinetic) sensations and perceptions in children of the third year of life; analysis and synthesis to clarify the prerequisites and factors that support the motor development of children in their third year of life. The conceptual and categorical apparatus of the study is specified: motor development of young children - changes in cognitive, emotional, volitional processes that contribute to the formation of movements in young children and additional concepts: movement (mental), which is performed by a child of the third year of life; motor activity; motor

\footnotetext{
${ }^{1}$ Candidate of Pedagogical Sciences, Senior Researcher in the Laboratory of Preschool Education and Upbringing of Ukraine,

Institute of Problems of Education of National Academy

of Pedagogical Sciences of Ukraine, Ukraine
} 
skills; adaptation to movement; motor skills. The concepts we create create a conceptual field of study of the problem of motor development of children in the third year of life, which is part of the methodological concept of its implementation. To ascertain the real state of motion sensations and perceptions in children of the third year of life, we set the task: to develop a toolkit of the ascertainment stage of sciens research work (SRW) in order to study the mental processes of children in the conditions of institution of preschool education; to identify, on the basis of the results of the ascertaining stage of the study, the levels formation of sensation and perception in the third year of life. The proposed games and game exercises, which make up the toolkit of ascertainment, allowed us to focus on the individual history of the development of feelings, perceptions in the child, to determine further the specifics and patterns of motor development of children in the third year of life. The general characteristics of the levels and the results of the study allow to state the fact of existence of $3 \%$ of children of the middle level of the formation of motor sensations and perceptions, which in turn directs further research to the development of technology of motor development of children, the main task of which is the development of meaningful perception of movements in children of the third year of life in conditions institutions of pre-school education.

\section{Introduction}

The transformation period that our country is experiencing is accompanied not only by the socio-economic downturn but also by the deterioration of children's health. Children remain the most vulnerable and most important link in the nation's health. Maintenance of social comfort and favorable conditions of stay in pre-school education institutions (PSEI), provision of conditions for motor development of children is one of the important tasks of pre-school education in Ukraine.

Modern living conditions of young children require rapid adaptation to the needs of the society, in which every minute changes the motor activity, which supports the process of mobile adaptation, leads to understanding the movement, mechanisms of its formation, control. The contradiction between compliance with the external, social requirements of the environment and the internal capabilities of the child's body, taking into account its motor experience, the formation of motor skills, the level of comprehension 
of the mechanism of movement, set the requirement to take into account the psychophysiological features of early childhood development (third year of life), level of fitness.

The physiological need for movement, the desire to move, and the need to master movement in order to provide one's own need for movement to interact with peers and play alongside, make it possible to consider the problem of motor development in children of the third year of life. At this age, the sensual and emotional underpinnings of future motivations for motor activity are laid to a greater extent. The task is to give the child the opportunity to feel the joy of movement and to create conditions for this, taking into account the determinants of motor activity.

The following scientists paid attention to the question of motion development: I. Sechenov and I. Pavlov (the doctrine of the mechanism of arbitrary motions), O. Bernstein, N. Krestovnikov (motor skill is a motive (dynamic) stereotype), which outlined the physiological basis of movement formation, its step-by-step mastery and automation, which forms the motor skill as an automated way of managing movements in a holistic act $[30 ; 31 ; 26 ; 27 ; 6$; 19]. Thus, O. Bernstein viewed the motor image of motion as a set of spatio-temporal characteristics of what would be performed on the periphery in real motion; from the standpoint of biomechanics and physiology distinguished its typical characteristics: the spatial-temporal parameters of real motion, geometric image, structures and characters of impulses, a localization site having topological ordering by the type of outer space or motor field of the individual [6]. P. Lesgaft attached importance to the peculiarities of the structure of the body, mechanics and physiology of movements, studied the interrelationships of the central nervous system and the human motor apparatus, formulated the progressive requirements of pedagogy of the upbringing of a young child, including the requirement for consistency of word and action in the relationship of the caregiver [22]. V. Gorinevsky, Y. Arkin, L. Chulitskaya summarized and continued the development of P. Lesgaft's ideas, substantiating the importance of taking into account the age peculiarities of children, the development of physical exercise and motion games $[11 ; 1 ; 33]$. Studies of movements, theoretical foundations of learning children movements were carried out by E. Levy-Gorinevskaya (quantitative and qualitative indicators in the development of movements in children), G. Bykova (methods, techniques of training movements, system 
of sequential training of basic movements at different ages) [4; 20]. Scientists dedicate research into the development of young children (N. Askarina, M. Schelovanov, M. Sheiko) [2; 3; 34]. E. Levy-Gorinevskaya investigated the patterns of development of children's motility [20]. D. Khukhlaeva studied the peculiarities of teaching children technically complex movements [16]. The efforts of scientists from various fields on the problem of the development of movements in children have been consolidated. In particular, under the supervision of O. Zaporozhets, a study of the development of arbitrary motions was carried out, and the regularities of the development of motility in children were substantiated [14]. Issues of dynamics of development of basic movements were considered by T. Osokin, G. Yurko, and E. Vilchkovsky [25;35;9]. The role of consciousness in the formation of motor skills in children has been investigated (O. Keneman, G. Leskov) [16; 21]. Formation of physiology of motor activity is conditioned by carrying out fundamental and applied researches in the field of medicine, which were carried out by L. Orbel, A. Krestovnikov [19; 24].

Conditions of formation of motor skills in children through auxiliary exercises were studied by G. Leskov [21]. T. Dmitrenko, E. Vilchkovskiy outlined the nature of motor skills, the role of psychological factor in mastering children movements, features of teaching children movements in consideration of the principles of didactics teaching children movements, methods and techniques of training, educational work in the process of learning movements; also highlighted the influence of the adult as a decisive factor in the development of young children, the development of movements and their peculiarities during games and classes $[9 ; 12]$.

For the most part, contemporary works are devoted to the development of children with special educational needs. The author's team (L. Borschevskaya, L. Vavina, I. Gudim, V. Zhuk, A. Kolupaeva, S. Litovchenko, N. Makarchuk, L. Prokhorenko, Y. Ribtsun, T. Sak, T. Skripnik, I. Sukhina, A. Taranchenko, O. Chebotaryova) take into account the peculiarities of movement formation in children, studying the development of different nosologies, investigating their correction in the conditions of PSEI [7].

At the same time, the historiographical sources considered do not allow to create a complete vision of the phenomenon under study in the context of psychological and pedagogical research. The issues of research into the factors and prerequisites of motor development of young children, includ- 
ing the third year of life, taking into account the processes of socialization of children and the impact of various forms of work in PSEI are left out; formation of movements in conditions of preschool education institutions during the free activity of children; development of mental processes in modern children during the direct and indirect guidance of the teacher. Also, the issue of adaptation of children of the third year of life, the isolation of the features of movement formation in modern children, taking into account the psychophysiological features of their development, the needs of children and their parents, changes in the subject-development environment of various types of PSEI not taken into account. It is kept separate by the action of the teaching staff and the parental community, which should together promote the motor development of children in the PSEI and at home. In order to reveal the problem of motor development of children of the third year of life, the focus is on the study of the formation of motor sensations and perceptions in children, namely the statement that will allow us to achieve the common goal, the object of study, where the object of our study is mental (cognitive, emotional, volitional) processes that affect motor development. To ascertain the real state of motion sensations and perceptions in children of the third year of life, we set the task: to develop a toolkit of the ascertainment stage of sciens research work (SRW) in order to study the mental processes in children in the setting of preschool education; to identify, on the basis of the results of the ascertaining stage of the study, the levels of sensation and perception in the third year of life.

The methodological basis of the research is the theory of personally oriented child-rearing; classic approaches to the formation of arbitrary personality behavior; state regulations on preschool education in Ukraine; scientific conceptual approaches to the organization of public preschool education; scientific views of V. Balsevich, N. Bernstein, E. Vilchkovsky, T. Dmitrenko, V. Zavatsky, G. Kostyuk, O. Makhlazov, A. Rivne [5; 6; 9; $12 ; 13 ; 18 ; 23 ; 28]$. Bibliographic method of studying library holdings, descriptions and bibliographic editions has been applied for systematization and classification of philosophical, psychological-pedagogical, medical literature (dissertations, monographs, articles in scientific collections and journals), determination of theoretical bases, content and structure of leading categories of research in young children; to determine the levels of motor (kinetic) sensations and perceptions in children; used the method of 
theoretical analysis to determine the criteria, indicators and levels of motor (kinetic) sensations and perceptions in children of the third year of life; analysis and synthesis to determine the prerequisites and factors that support the motor development of children in their third year of life.

\section{Conceptual field of study}

The studied sources of psychological and pedagogical, medical literature, scientific views of V. Balsevich, N. Bernstein, E. Vilchkovsky, V. Zavatsky, T. Dmytrenko, G. Kostyuk, O. Makhlazov, A. Rivne allowed to clarify the conceptual and categorical apparatus of the research: motor development of young children - changes in cognitive, emotional, volitional processes that contribute to the formation of movements in young children; movement (mental) performed by a child of the third year of life an action determined by the objectivity, activity, connected with the past and present experience of the child; movement has levels of construction and control; motor activity - a system of motor actions that ensure the interaction of the child with the environment; motor skill - an automated way of managing the constant state of the interior. Individually acquired motor acts formed conditionally in a reflex manner. The basis of the development of motor skills is the formation of temporary connections between different departments of the CNS as a result of repeated repetition of the same type of exercises; adaptation to movement - the set of physiological reactions that underlie the adaptation of the child's body to movement, environmental conditions in which the movement is constantly changing, and aimed at maintaining a relatively constant state of the internal environment (homeostasis); motor skills - acquired on the basis of knowledge and experience the ability to automatically control movements $[5 ; 6 ; 9 ; 12 ; 13 ; 18 ; 23 ; 28]$. The concepts we create create a conceptual field of study of the problem of motor development of children in the third year of life, which is part of the methodological concept of its implementation.

\section{The criteria for the formation of motor sensations and perceptions in children of the third year of life}

We understand that the development of a young child is an individual story of the development of his feelings, perceptions, perceptions, feelings, aspirations and other reflections of objective reality, the formation of the 
«subjective world» of the individual, his consciousness. In the process of knowing the world, the child establishes effective connections with him during his own activity. Moving and acting, the child satisfies his or her own needs by mastering and supporting them through communication. Language, as the main means of communication, becomes a means of mastering social experience, the emergence and development of thinking actions, the transition to higher stages of development of thinking. It is the mental processes of sensation and perception that are widespread in children of the third year of life along with the language, the awareness of their own «I». The third year of a child's life is characterized by qualitative features of the development of his mental processes and by what types of activity the child is included in and how he or she satisfies his or her own needs and requirements in this activity [18].

For the classification of mental processes, we use the scientific vision of G. Kostyuk [18]. The content and vitality of the mental processes, which is the principle of their division into three classes (cognitive, emotional, volitional), leads to the study of the child in the third year of orientation in itself, in how much it knows objects or phenomena, their connections and attitude; processes that reveal the child's attitude to himself and to the action he performs; processes, which consist in the organization and regulation of its substantive actions, in view of the objective activity. These processes are considered in unity, we refer to features of motor development of children of the third year of life.

The essence of motor development of young children (the third year of life) is the feeling and perception of the child's movement, its ideas about movement; desires and needs for movements, experiences during movement and attitude of the child to own movement; the child's desire to act with objects, to articulate movements, to be able to act meaningfully (to move). We distinguish in the structure of motor development of children of the third year of life the following components: cognitive, emotional, activity-volitional. Accordingly, the cognitive criterion reveals quality, intensity, duration of sensations; selection of perceived object among others, experience of motion perception, meaningful perception of movement (direction, speed). The emotional criterion reflects the desire to move, the need for movement, emotions, intensity, stability, duration of the manifestation of the experience; the attitude of the child to their own movement. Activi- 
ty-regulation (associated with volitional regulation of movements) criterion characterizes the child's desire to act, articulation of movements (when the word is ahead of the action), the ability to delay their own actions.

\section{Toolkit of verification}

The analysis of historiographic sources (O. Bernstein, O. Zaporozhets, I. Pavlov, I. Sechenov) made it possible to conclude that it is expedient to determine the above mentioned indicators of formation by focusing on the following processes: the sense of movement, namely the quality of the senses that are determined. the properties of the objects that cause them; the intensity of the sensations, their quantitative characteristics, which depend on the strength of the stimulus; duration of sensations, their temporal characteristics, duration of stimuli $[6 ; 14 ; 26 ; 27 ; 30 ; 31]$. Next, pay attention to the child's perception of movement. We are interested in singling out a child's perceived object among other objects, having previous experience of motion perception, meaningful motion perception. When determining a child's prior experience of motion perception, it is important to find out whether the child recognizes the movements, whether he or she has an idea of the movements. To the sensible perception of movements we have included: orientation of the child in the direction of movement, which will be set in the direction of the stimulus; perception of the speed of movement, which will be determined by the speed at which the stimulus moves and the volume of the stimulus, as the subjective perception of the power and intensity of the sound of the child. The above indicators of the formation of motor sensations and perceptions in children of the third year of life are classified as a cognitive component by cognitive criterion.

In the first stage, in order to study the child's third year of life, the motion (quality of the senses), which are determined by the properties of the objects that cause them, we offer the children a game «Play with the ball». We tell the kids that today they are greeted with toys that live with them in a group room. We encourage children to consider soft toys and choose one with which the child will play. To get acquainted with the selected toys, we recommend that children take one ball (different colored balls) out of the basket. The teacher advises children to consider the balls.

Playing exercise has some features: children play in the number of 1 to 3 people, the balls are different in color with the names of the children; 
balls are the same size, small, fit well in the child's hand; made of rubber. Medium size soft toys of at least ten (Bunny, Chanterelle, Cat, Dog, Teddy bear, etc.) so that the child is able to grasp the toy foot with his or her hand and place the ball in the toy foot. For example, when choosing a Bunny, the teacher should pay attention to his posture. It must move, not be made solely for perception in a static position.

The research is conducted by three adults, preferably two educators and a psychologist, considering the speed of the game exercise and the processes of forming feelings and perceptions in children, drawing children to their own experience and mastering new content that the teacher offers during the game exercise. This amount of adults is required to fully capture objective information when seen, heard. To determine the orientation of the child in the object, its properties, the adult captures the actions of the child: considers the ball, how it interacts with, or acts with, recognizes, the movements of the child. When an educator proposes to play with the ball, another adult captures the movements of the child as he rolls the ball from one hand to the other (from himself), when he hits the ball, hits the ball on the floor, rolls ball to the teacher. We also record the child's emotions during movements, articulation of movements. Transition of the child to another game exercise is provided by the questions: than does it play? Does she like to play?

To investigate the intensity of sensations, we determine their number, strength and weakness, which depend on the strength of the stimulus. We encourage children to play further if the desire to play does not go away. The teacher demonstrates the following actions with a toy. Commenting on his own actions, he takes the Bunny, kneels, gives the Bunny a ball in his paws and shows how the Bunny can roll from one paw to another ball, then how he hits it with his back foot, hits the ball on the floor with his front paw , rolls the ball to the teacher. Adults record how many seconds or minutes a child places a toy animal on its lap, how it controls the toy so that it can act on the ball. Whether the toy is a strong or weak stimulus (the number of sensations depends on the number of analyzers involved (visual, auditory, kinetic, tactile, etc.). We also record the emotions of the child, articulation of movements, impressions of actions with the toy : Are you satisfied (Bunny, Fox, Cat, etc.) playing with the ball? Is the child satisfied with the game? We record the children's answers in writing. 
To study the feeling of movement (duration of sensations, their temporal characteristics, depending on the duration of the stimulus), the teacher records the duration of the stimulus (time (sec, min.)), When the child acts with the ball, with a toy, chooses a toy, considers $m$ he plays with himself, he plays, controlling the toy - he acts with the stimulus. That is, throughout the game exercise, one of the educators captures all the action with the ball and the toy and focuses on the sensation of movement, the second educator captures the child's perception of movement. The third teacher, during the deployment of the game exercise and its existence, completion, captures the duration of the child's movements when he acts alone with the ball, controls the toy and ball (examines, reflects, hits the floor, rolls, stops, catches, etc.)).

To determine the progress of the motion perception process (highlighting the perceived object among other objects) in children of the third year of life, we ask children to find a familiar ball among moving toys. The teacher activates balls of different sizes (up to ten in number), among which children are familiar with small balls. He suggests finding them among balls that roll in different directions. We record whether each child will find their ball when they roll in different directions; when the teacher, after collecting all the balls, flips them with his foot, once again bringing them together; when the teacher pours all the balls over the top.

To identify the experience of motion perception in a child, we deploy a «Moveable Movement» exercise, inviting children (no more than 3-5 people) to view several children's cartoons (within the age of children) during which children should name familiar movements (go, run, sits, stands, throws the ball, etc.), who carry out cartoon characters, coordinating children's answers with questions. As you continue playing, we encourage children to play with the ball (do you have a ball, how are you going to play it? Show and name the moves!). We capture children's comments while watching cartoons, focusing on the names of the movements and during the second part of the game exercise, recording the actions with the ball and whether the child calls his own actions and articulates the movements.

We study the sensed perception of movements, revealing the orientation of the child in the direction of movement, which is set in the direction of finding the stimulus; perception of the speed of movement, determine the speed at which the stimulus moves; by the loudness of the stimulus, as the subjective perception of the power and intensity of the sound of the child. 
Finding a Ball game encourages a child (3-5 children) to find a ball among different toys in a group room. Come up and get the ball, bring it and put it in the basket. It is important for the educator in this matter to grasp the time when the child will turn to him for help (in gaze, treatment, state of confusion) and to point the child in the direction where the ball was hidden with his hand (left, right, in the car or in the pupa). We record the movements of the child (goes, leans, examines, searches, takes, articulates, gets, carries, runs, goes slowly), which she performs by finding the ball; emotional state, fulfillment of the verbal task of the teacher (to approach, to take, to bring, to put in the basket).

We continue to play with the ball during the Quick Slow Exercise. We invite 3-5 children to her and we ask her to perform the ball action quickly and slowly. The teacher sits opposite the child (the distance from the child to the teacher is $40-50 \mathrm{~cm}$., Marked with a strip), explains the game rules (I will roll the ball to you slowly, and you will roll to me quickly, then vice versa (three times). The teacher demonstrates by commenting on the child's own actions and actions, and invites the child to comment on the ball action himself. We record the child's comments during six ball rolling.

The perception of the stimuli's publicity as a subjective perception of the strength and intensity of the sound of the child, is determined during the deployment of the game play «Listen to the ball», subject to the following conditions: localization in space, the same amount and strength, the intensity of the ball hitting the floor, about the wall. We record the fact that the child identifies the ball - the stimulus and whether the child guesses that in the room next to someone beats the ball on the floor, against the wall, how loud, loud, quiet, almost inaudible, etc.

The first and second stages of the ascertainment must take one week. In the second stage, we focus on whether the child was impressed with the ball games? Knowing that the power (intensity) of the emotion that is causing them, after seven days of interruption, do we put small and big balls in front of our children and see if they pay attention to them? Will they take hands, act with the balls, repeat the familiar actions, unless we invite them to do so? During observation we pay attention to the child's desire. What does she want? In the first place should be an irritant: communication with an adult (the child goes or runs and shows the ball to an adult); independence (the child plays, sees the ball); playing next to a peer (showing a baby a ball); 
playing with an adult (moving the ball to the teacher); game with the subject (considers, rolls, throws the ball or takes the toy and the ball and controls it). Balls in this case are an additional stimulus - «auxiliary», because the child already has experience of movement with them after games. Observe whether there is a general relationship between the child and the stimulus? Which stimulus has less effect on the baby? Which stimulus prevails?

The situation of the child's attitude to the stimulus when the stimulus is movement. We offer the child a moving game «How do I move?». The task of the teacher is to find out whether the movement is in the first place for the child, whether it is an irritant and not an object (a toy). In front of the child (one person), place toys on the table or bench: new and familiar. We offer the child two options for the deployment of the situation: if he (he) wants to get a new toy, then he should approach it quietly, slowly, calmly. If he wants another toy, he can run to it, hurry or just go for it without following the rules of the game. Observe the child and record its actions, manifestations of experience. Namely: whether there is a general experience of the situation (the attitude of the child to his own movement). We also record the stability of the experience (the seconds when the baby moves from where he or she is to the toy (the moment he, she takes it into his, her hands)) during movement, which is a reflection of the child's situational attitude to the stimulus (to movement). If the child shows (shows) attitude to the stimulus (movement), it means - she is aware of it. That is, it clearly fulfills the condition of the caregiver - to go quietly, quietly, slowly from beginning to end. The emotional coloring of this relation to the caregiver's task and to the movements she performs from beginning to end is important. Stability of the experience (seconds) is the duration of the manifestation of the experience, along with the will of the child, their manifestation. Also it is necessary to take into account the mental state of the personality: the child is calm, excited, moved, embarrassed, sad, cheerful, depressed, etc. In order to clarify the results of the mobile game «How I move», we conduct game exercises «Question and answer». Namely, we ask the child: what are you doing? What do children do? How are you doing? How are we going? How does Cat go? As Masha walks (the girl's name is Masha). How do you go? What is a Kitten? What can Masha do? What do you know? How does Kitten throw the ball? How does Masha throw the ball? How do you throw the ball? Pay attention to whether the child understands the issue? What are the 
questions? Is the joy of movement going? (Here she decided to go, quietly, quietly, slowly. She took the new toy in her hands, she was satisfied with her own movements. She went without a doubt, anger, tension. She took the toy, plays a new toy). We also perform game exercises to help determine which of the stimuli prevails. Let's play the plot when the Teddy bear runs to his mother, we ask how the Teddy bear runs to his mother? Hurry or not? Worried or not? Here's a Mouse Rolling the Ball; The cat offers to jump Fox together and others. During emotionally colored subjects, the teacher has the opportunity to once again see the reality of the manifestations of children by watching them.

We also create opportunities for the teacher: to trace the dependence of the experience force on the strength of the impressions that cause them; take into account the force of the experience, which is caused by the connection of impressions with the needs of the child, the assessment of the child of the objects with which it plays, to determine the subjective state of the child at the time of each game. Along with such opportunities, the teacher should remember that the duration of the experience depends on the content of the objects that cause it, namely the content that the teacher puts into those objects during the game, taking into account the nature of the needs, wishes of the child with whose satisfaction they are related [18].

The experience is manifested in the attitude of the child. Attitude of the child to his own movement - active manifestation of the child's need for basic movements, which are manifested in agreement and decision to act. Active child - A child who acts, interacts, shows action. The child agrees - answers us, gives permission; its solution is the search for ways and answers, the process of completing the case, its completion. In the child of the third year of life the subject activity prevails. During a subject activity that prevails even in the game, it encourages the child to do this activity the object. The child has a need to act on the subject. However, when moving with an object or objects, the child moves: it reaches or grabs, grabs, climbs, crawls, jumps, runs, etc. It moves and thus satisfies its own need for movement (motions) senselessly. During movements, the child shows an attitude towards the object and its attitude is included in this attitude. Also the action is included in the subject and motor activity. Therefore, we can first assume that a motor action is a process that lies in the activity in which that action is involved. We observe a combination of subject 
and motor activity. Investigate the existence of movements for children; whether children observe their own movements; to detect the existence of attitude not only to the subject, but also to our own movements, we can use traditional methods. In addition to the method of observation, we offer children success situations - setting the caregiver such tasks for the child's age, as a result of which the child independently achieves its goal, and which create an opportunity for the child to express themselves. Such situations can be deployed in the course of organized or free (independent) activity of children associated with movements, provided the teacher uses the techniques: support, positive evaluation, assistance, showing, explanation, guidance, encouragement, wonder. We also involve children in the game Mirror, which is desirable to be held in a music hall or choreography room. For classical and contemporary music ( 2 tracks in turn), we invite children to move freely (dance, sing, walk, etc.) and observe their movements in a large mirror, which is placed on the wall for choreography classes. We fix: how the child evaluates himself in the mirror; how it relates to one's own movements; whether she is positively attuned to herself and her movements, to the exercise of the movement; what experiences capture her as she moves, when she considers herself in the mirror.

We refer to the activity-volitional component as the activity-regulatory criterion associated with the volitional regulation of movements in children of the third year of life. Several criteria have been selected for this criterion, which, in our opinion, reveal the manifestations of movements at the stage of accompanying them with a word, which will allow to ascertain the meaningfulness of the child's motor actions. In order to identify the child's desire to act with an irritant, and to act with an irritant, we offer her a game of ball draw. We remind you that the children are familiar with the balls. The kindergarten teacher should invite children (up to 3 people) to look at paints of different colors and choose the one that is most comfortable. Then the teacher draws attention to himself and performs movements and actions with the ball: "I chose yellow paint, I want to paint the track. I have a ball in my hand. See how I hold it (takes three fingers and holds it firmly). I hold fast so that the ball does not run away from me. Here, I dip the ball into the paint by half and run the ball over a piece of paper (the sheet of paper is fixed to the tray with the walls). I'm starting to draw. I draw the ball from left to right (mirror image) $»$. Now pay attention to what the child 
watches - the ball or the movements of the caregiver's hand, his fingers holding the ball? Caregiver: "Now I suggest you try.» Children place the ball between three fingers, dip in paint and draw lines (2-3). The teacher then draws attention to the lines and asks the children whether they are satisfied with the drawing or not? We continue to play and invite each child, holding the ball in their hands all the time, to show how the ball jumps on the track it has drawn after the teacher shows. Notice the traces left by the ball are circles of different sizes. For jumps, children can dip their balls in paint of a different color. At the end of the game, children should roll the ball on their tracks, releasing the ball as the caregiver did. As a reminder to watch the actions and movements of children, we offer adults ( 2 people), in addition to a teacher who plays with children. It is important to note the following questions: Does the child act in accordance with the task of the caregiver; draws the track independently, draws 2-3 tracks alone or with the help of the teacher, his intervention; plays with the ball when the ball jumps on the tracks as it rolls on them. The emotional state of the children and the presence of desire during the movement is observed by the second adult and captures what was seen. It is important to understand what your child wants when drawing: to play with the ball; to move; are the aspirations not clear, almost nonexistent? Focuses on your fingers, arm movements or balls?

The next indicator for the activity-regulatory criterion is the articulation of movements by children (when the word is ahead of the action). In order to detect such manifestation, we offer the teacher a mobile game «Interview». Exactly the teacher, because he has to choose the role of a correspondent, and during the free (independent) play of children who is full of movement, to find out the answer to one question: what are you doing now? The teacher approaches the child with a microphone, asks a question, and the other teacher fixes the answer while away. It is important to focus on what the child is manifesting: silent; names its own name and movement (Masha runs); says, «I'm running,» «I'm going,» or «I'm,» and calls other moves. We also suggest using a surveillance method that aims at fixing the child's articulations and movement. We are interested in the question: does the word go beyond the action of a child? Therefore, the teacher should listen to the child while playing and communicating with toys, peers, to record manifestations when the word is ahead of the action of the child (Masha will bring a ball; I will bring a ball). 
We examine such an indicator as the child's ability to delay his or her own actions, which indicates the reasonableness of an arbitrary action (movement), during the game «Self-master». Let us dwell on the fact that before such a game, the teacher must familiarize the children in advance with the game play «Keep Yourself», which will help to further develop the game «Self Master». The game exercise is aimed at the child's conscious perception of the adult's request and the ability of the child to perform it on the one hand, and to explain to the child how to do it to fulfill the adult's request on the other, while the desire comes first in the child. The teacher plays the plot: Bunny's mom asks little Bunny not to eat sweet carrots now, but to wait for dinner and eat carrots after dinner. And Bunny really wants carrots. What Do Bunnies Do? Let's teach him how to «keep his cool» How? I'll show you. The teacher shows emotionally and shows how the Bunny hugs himself with both hands (soft toy, bunny paws can make movements). Invites children to repeat movements, commenting on their actions, saying for Bunny «I will hold myself in my hands.» It is advisable to repeat the exercise several times. In addition, the caregiver should familiarize children with the hourglass as an object that can measure time, and we can see this measurement process, and hold the clock, watch the sand passing through a small hole, and measure the number of seconds or intervals when the baby has to wait. When children play such an exercise several times, have an idea of the action of «take hold of themselves» and are familiar with the hourglass, we deploy the game «Self host». We suggest the child (1 child) to get out of the smartphone cabinet (children's phone (toy)) and continue to play with it only after the sand in the hourglass is over. The tutor continues: «If you find it difficult to hold back, you can put your arms around yourself, as then, while playing,» hold yourself in your hands «and wait for the sand to finish. The caregiver announces the proposal and goes to observe the movements, actions of the child. Observation is indirect and short-term with fixation of movements of the child and its emotional manifestations. We record the child's acceptance of the teacher's proposal; whether the baby waits quietly and after the sand in the clock picks up a toy and plays with it; how many seconds he starts to worry and look around; how many seconds will take advantage of the caregiver's proposal and «take yourself in hand»; after how many seconds it will not last, it will take the toy and play. We are interested in the duration of the expectation and unfolding of an event for 
each child individually, their personal manifestations of the ability to delay their own movements, emotions and manifestations of volitional regulation of movements.

\section{Conditions and factors}

Human movements are influenced by factors that, under certain conditions, acquire and improve. Knowing society as an objective reality, we view a variety of facts, including pedagogical, as inherent in the events of objective reality. These facts are the causes and conditions in which the movements of children are formed. In the context of research, we consider prerequisites and factors as such, where the cause is a fact or phenomenon that gives rise to a condition or causes a change in it. The prerequisites that affect the motor development of children in the third year of life are: social and pedagogical prerequisites - circumstances that predetermine, promote or influence the development of movements of children in the third year of life. Factors that also affect the development of movements: socio-pedagogical factors that we consider as circumstances that predetermine, promote and influence the formation in the third year of life processes of feeling, perception of movement, perception of movement, emotional and positive attitude to exercise during different activities.

Using the characteristic of the categories of dialectics «cause», «consequence», «condition», according to V. Kasyan and the reference source base, the consequence is understood as the result of the action of causes and prerequisites and as the cause or prerequisite for further changes in the mental processes that occur in children of the third year life [15]. We consider the preconditions of motor development as preconditions - the circumstances that cause, promote, influence the development of movements in children of the third year of life. We take into account that cause and effect are mutually dependent: they are genetically linked, asynchronous in time (first cause, then consequence). The emergence of an effect influences the cause, causing its change, in particular through indirect relationships, which are the cause - we determine the preconditions for the motor development of children in the third year of life. Prerequisites are circumstances without which movement is impossible. Circumstances - the facts that contribute to, influence, the development of movements. Facts are understood as manifestations of changes that actually took place during the study and are 
objectively present. The above preconditions and factors will enable us to form an objective opinion about the cause and effect relationships between them for the existence of determinants of motor activity, their peculiarities, specificity; identify those that are likely to change in a pre-school setting and with the support of the parent community.

During the study we take into account the determinants of motor activity, characterized by V. Balsevich [5]. The biological determinants of motor activity are determined by the fact that the underlying motions and motor actions of the child are the result of the activity of the organism as a living system. Movement, regardless of whether it is performed under the control of consciousness, at the behest of higher cerebral cortex or carried out by the mechanism of unconditioned reflex, yes or no, is accompanied by the deployment of physiological mechanisms and biochemical processes to ensure the energy of movement [6]. The purpose of socio-cultural determinants of the development of a child's organism is to support homeostasis, to achieve the desired characteristics of its condition, the level of quality and reliability of maintaining the constancy of the internal environment of the child's body, optimizing the interaction of the child with the external environment. The socially determined need and need of the organism and the individual in support of homeostasis, maintenance of morphological, functional, biomechanical, psychological conditions of realization of genetic and socio-cultural program of their development in ontogeny meets with factors that have a direct influence on the development of the child.

\section{Findings}

The above toolkit for the implementation of the ascertaining stage of the study, which was introduced into the educational process of pre-school establishments in Zhytomyr (Ukraine) in groups of early age with children from 2 to 3 years, allowed to determine the levels of motor movement and perception in children and give a general description of them. $0 \%$ of children who are actually oriented in the object, its properties, act with it, repeat the movements of the teacher are considered high; perform movements that the educator demonstrates, are positively inclined to exercise movements, communicate with the teacher, articulate movements that the teacher demonstrates; agree with the teacher's tasks and suggestions, emotionally satisfied with communication, play. The duration of the stimulus 
action is 30 seconds; the duration of movements and guidance of the toy exceeds one minute; such children find a familiar toy, name what they see on screen and their own movements; oriented in the direction of movement and volume of the stimulus; recognize the stimulus; have experience playing with stimuli; besides the stimulus, as an object, there are other stimuli: communication with an adult, playing near a peer, independence; are in a situation of irritation during movement and games, stimuli, as an object and other stimuli, have a positive effect on the child and dynamic. There is a situation of the child's attitude to the movement, its experience; the stability of the experience exceeds 30 seconds; Shows attitude to own movement as an irritant - aware of movement. Emotionally positive self-esteem, positive self-esteem, like their own movements. The child is covered by the experience of moving; follows the movements of the teacher's hand, his own movements of the hand, independently chooses the color of the paint. He tries to hold the ball firmly, makes moves; seeks movement and play; focuses on movements. The word is ahead of the action. Uses «hold in your hands», able to delay their own movements (at least 30 seconds).

The average level is attributed to $3 \%$ of children who are oriented in the object, its properties, act with it, repeat the movements of the teacher; perform movements that the educator demonstrates, are positively inclined to exercise movements, communicate with the teacher, articulate movements that the teacher demonstrates; agree with the teacher's tasks and suggestions, emotionally satisfied with communication, play. Duration of the stimulus action up to 30 seconds; duration of movements and guidance of the toy up to 1 minute; such children find a familiar toy, name what they see on screen and their own movements; oriented in the direction of movement and volume of the stimulus; recognize the stimulus; have experience playing with stimuli; there are other stimuli besides the stimulus as an object: communication with an adult, playing near a peer, independence; are in a situation of irritation during movement and games, stimuli as an object and other stimuli have a positive effect on the child and dynamic. There is a situation of the child's attitude to the movement, its experience; endurance of up to 20 seconds; Shows his attitude to his own movement as an irritant - he is aware of the movement for teacher intervention. Emotionally positive attuned to herself, positively evaluates herself, she likes her own movements with the assistance of the caregiver. The child is covered by the 
experience of moving; Uses «hold in your hands», capable of holding its own movements (less than 20 seconds).

$34 \%$ of children who are oriented in the object, its properties, act with it, repeat the movements of the teacher are considered as sufficient; perform movements that the educator demonstrates, are positively inclined to exercise movements, communicate with the teacher, articulate movements that the teacher demonstrates; agree with the teacher's tasks and suggestions, emotionally satisfied with communication, play. Duration of the stimulus action up to 30 seconds; duration of movements up to 1 minute; such children find a familiar toy, call the movements seen on the screen; oriented in the direction of movement; recognize the stimulus; have experience playing with stimuli; the subject is the main stimulus. There is a situation of the child's attitude to the movement. Not always emotionally positively attuned to himself, in most cases, positively self-esteem. The baby is covered by emotions of different nature as she moves.

The initial level includes $63 \%$ of children who navigate, interact with the object, repeat the movements of the teacher; perform movements that the teacher demonstrates, are not always positively oriented to the implementation of the movements, communication with the teacher, not always articulate the movements that the teacher demonstrates; agree with the tasks and suggestions of the teacher for the intervention of the teacher himself, satisfied with communication, passive during the game. Duration of the stimulus action up to 30 seconds; duration of movements up to 1 minute; such children find a familiar toy, name the movements seen; oriented in the direction of movement; recognize the stimulus; have experience playing with stimuli; the subject is the main stimulus. There is a situation of a child's attitude to the movement for teacher intervention. Not always emotionally positively attuned to himself, in most cases, positively self-esteem. The baby is covered by emotions of different nature as she moves.

The general characteristics of the levels and the results of the study allow to state the fact of existence of $3 \%$ of children of the middle level of the formation of motor sensations and perceptions, which in turn directs further research to the development of technology of motor development of children, the main task of which is the development of meaningful perception of movements in children of the third year of life in conditions institutions of pre-school education. 


\section{Conclusions}

On the basis of the conceptual field of research, criteria and indicators, the developed toolkit of ascertainment, the levels of the formation of motor sensations and perceptions in children of the third year of life in the conditions of a preschool education institution were investigated and determined.

The proposed games and game exercises, which make up the toolkit of ascertainment, allowed us to focus on the individual history of the development of feelings, perceptions in the child, and further define the specifics and patterns of motor development of children in the third year of life.

The social determinants of motor activity include the educational effects experienced by the child on the part of parents, caregivers, and close relatives. We understand that the study of the determinants of motor activity is necessary in view of the fact that the children of the third year of life live in the family, are at the time of the study under the influence of the educational process and processes that are carried out in relation to the children of adults; children already have experience of movements. At the same time, we consider biological and sociocultural determinants as existing independently of us on the one hand and as ones that we can influence directly in our research on the other.

We see the prospects for further research in the development of the technology of motor development of children of the third year of life in the conditions of a preschool education institution.

\section{References:}

1. Arkin, Ye.A. (1931). Rebenok ot goda do chetyrekh let. M., L. Uchpedgiz.

2. Askarina, N.M. (1977). Vospitaniye detey rannego vozrasta. Moskva. Prosvyashcheniye.

3. Askarina, N.M., Shchelovanov, N.M. (Red.). Vospitaniye detey rannego vozrasta v detskikh uchrezhdeniyakh. (1972). Moskva: Prosveshcheniye.

4. Bykova, A.I. (1962). Obucheniye detey doshkolnogo vozrasta osnovnym dvizheniyam. Moskva: Uchpedgiz.

5. Balsevich, V.K. (2009). Ocherkipo vozrastnoy kineziologii cheloveka. Moskva: Sovetskiy sport.

6. Bernshteyn, N.A. (1966). Ocherki po fiziologii dvizheniy i fiziologii aktivnosti. Moskva: Meditsina.

7. Borshchevska, L.V., Kolupaeva, A.A. (Red.). (2010). Putivnik dlya batkiv ditey z osoblivimi osvitnimi potrebami. Kiiv: TOV VPTS Litopis - KHKH.

8. Burlay, V.G., Gnatenko, O.Z., Maydannik, V. G. (Red.) (2018). Propedevtichnapediatriya. Vinnitsya: Novakniga. 
9. Vilchkovskiy, Ye.S., Kurok, O.D. (2008). Teoriya i metodika fizichnogo vikhovannya ditey doshkilnogo viku. Sumi: VTD Universitetska kniga.

10. Volkov, V.M, Stepochkina N.A., Trunin V.V., Vasilyeva, V.V. (Red.) (1984). Fiziologiya cheloveka. Moskva: Fizkultura i sport.

11. Gorinevskiy, V.V., Shmidt, S.O. (Red.) (2007-2014). Moskovskaya entsiklopediya. (Tom I. Litsa Moskvy: v 6 kn.).

12. Dmitrenko, T.I. (1979). Teoriya i metodika vikhovannya ditey rannogo ta doshkilnogo viku. Kiiv: Znannya.

13. Zavatskiy, V.I. (1993). Fiziologichna kharakteristika rukhiv yak tsilespryamovanoi povedinki lyudini. Lutsk.

14. Zaporozhets, A.V. (1960). Razvitiye proizvolnykh dvizheniy. Moskva. Uchpedgiz.

15. Kasyan, V. I. (2004). Filosofiya. Kiiv: Znannya.

16. Keneman, A.V., Khukhlayeva, D.V. (1985). Teoriya i metodika fizicheskogo vospitaniya detey doshkolnogo vozrasta. Moskva: Prosveshcheniye.

17. Kistyakovskaya, M.YU. (1970). Razvitiye dvizheniy u detey pervogo goda zhizni. Moskva: Prosveshcheniye.

18. Kostyuk, G.S. (1968). Psikhologiya: pidruchnik dlya pedagogichnikh vuziv. Kyiv: Radyanska shkola.

19. Krestovnikov, A.N. (1951). Ocherki po fiziologii fizicheskikh uprazhneniy. Moskva: Fizkultura i sport.

20. Levi-Gorinevskaya, Ye.G. (1955). Fizicheskoye vospitaniye detey doshkolnogo vozrasta. Moskva: APN RSFSR.

21. Leskova, G.P., Butsinskaya, P.P., Vasyukova, V.I. (1981). Obshcherazvivayushchiye uprazhneniya v detskom sadu. Moskva. Prosvyashcheniye.

22. Lesgaft, P.F. (1968). Izbrannyye trudy po anatomii. Moskva: Izd-vo AN SSSR.

23. Makhlazov, O.R. (2016). Psikhologiya ta psikhofiziologiya upravlinnya rukhovoyu diyalnistyu. Kyiv: Evroliniya.

24. Orbeli, L.A. (1938). Lektsii po fiziologii nervnoy sistemy. Izbrannyye trudy. (T.2.) M.,- L., Medgiz.

25. Osokina, T.I. (1986). Fizicheskaya kultura v detskom sadu. Moskva: Prosvyashcheniye.

26. Pavlov, I.P. (1951). Uslovnyy refleks. M. - L. Izd-vo AN SSSR.

27. Pavlov, I.P. (1951). Lektsii prorobotuvelikikhpivkul golovnogomozku, Kiiv. 28.Rovniy, A.S. (2014). Fiziologiyarukhovoi aktivnosti pidruchnik.Kharkiv.

29. Sagatovskiy, V.M., Kalniy, I.I., Zaichenko, G.A. (Red). (1995). Filosofiya. Kiiv: Vishchashkola.

30. Sechenov, I.M. (1961). Refleksygolovnogomozga. Moskva: Izd-vo AN SSSR. 31.Sechenov, I.M. (1947). Izbrannyye filosofskiye i psikhologicheskiye trudy. Moskva: Uchpedgiz.

32. Ukrainska radyanska yentsiklopediya. (1983). (Tom 9.POPLUZHNE_ SALUIN). Kiiv. Golovna redaktsiya Ukrainskoi radyanskoi yentsiklopedii.

33. Chulitskaya, L.I. (1926). Vospitaniye rebenka do 3-kh let. L.: Priboy.

34. Sheyko, M.K. (1959). Rankova gimnastika v dityachomu sadku. Kiiv: Radyanska shkola.

35. Yurko, G.P. Spirina, V.P. Sorochek, R.G., Uvarov, Z.S. (1987). Fizicheskoye vospitaniye detey rannengo i doshkolnogo vozrasta. Moskva: Prosvyashcheniye. 